\title{
Analisis Faktor-Faktor Kualitas Pelayanan Terhadap Kepuasan Pasien Rawat Inap Di Rumah Sakit Al-Islam Bandung
}

\author{
Rahmadianti \\ Program Studi Manajemen \\ Sekolah Tinggi Ilmu Ekonomi STAN IM, J1.Jakarta No.79 Bandung \\ Email : rahmadianti0681@gmail.com
}

\begin{abstract}
ABSTRAK
Penelitian ini dilakukan di Rumah Sakit Al-Islam Bandung. Masalah yang dirumuskan dalam penelitian adalah bagaimana tingkat Tangible (keberwujudan), Empathy (empati), Responsiveness (ketanggapan), Reliability (keandalan), Assurance (jaminan) pelayanan dan kepuasan pasien rawat inap serta seberapa besar pengaruh Tangible (keberwujudan), Empathy (empati), Responsiveness (ketanggapan), Reliability (keandalan), Assurance (jaminan) pelayanan dan kepuasan pasien rawat inap.

Metode penelitian yang digunakan adalah metode penelitian survey, jumlah populasi sebanyak 107 pasien. Dengan menggunakan rumus dari Slovin dan menggunakan taraf kesalahan $(e)$ sebesar 5\%, maka jumlah sampel yang di ambil sebanyak 84 orang. Teknik analisis data yang digunakan adalah teknik analisis korelasi untuk mengetahui derajat keeratan hubungan antar variabel penelitian dan teknik analisis jalur untuk mengetahui pengaruh baik langsung maupun tidak langsung variabel bebas terhadap variabel terikat.

Hasil perhitungan menunjukkan Keberwujudan, Empati, Ketanggapan, Keandalan, Jaminan berpengaruh signifikan terhadap kepuasan pasien.

Hasil penelitian menunjukkan bahwa pengaruh masing-masing variabel kualitas pelayanan yang terbagi dalam variabel Keberwujudan, Empati, Ketanggapan, Keandalan, Jaminan terhadap kepuasan pasien berbeda-beda tingkat kontribusinya. Namun apabila variabel kualitas pelayanan dilaksanakan secara terpadu, pengaruhnya kuat terhadap kepuasan pelanggan.
\end{abstract}

Kata Kunci : Keberwujudan, Empati, Ketanggapan, Keandalan, Jaminan, Kepuasan

\section{ABSTRACT}

The research was conducted in Al-Islam Hospital Bandung. Problem formulated in this study as follows: What level of Tangible, Empathy, Responsiveness, Reliability, Assurance services and patient satisfaction and how much influence Tangible, Empathy, Responsiveness, Reliability, Assurance services and patient satisfaction.

The research method used was survey research methods, the population of 107 patients. By using the formula of Slovin and use standard errors (e) of 5\%, then the number of samples take in this study as many as 84 people. Data analysis techniques used were correlation analysis technique to determine the degree of closeness of the relationship between the research variables and path analysis techniques to determine the effect of directly or indirectly, the independent variable on the dependent variable.

The results of the calculation show that Tangibility, Empathy, Responsiveness, Reliability, Assurance have a significant effect on patient satisfaction. 
The results showed that the influence of each variable of service quality was divided into variables of Being, Empathy, Responsiveness, Reliability, Guarantee on patient satisfaction with different levels of contribution. However, if the variable service quality is implemented in an integrated manner, it will have a strong effect on customer satisfaction

Keywords : Tangible, Empathy, Responsiveness, Reliability, Assurance, Satisfaction

\section{PENDAHULUAN}

Rumah sakit sebagai penyedia jasa pelayanan kesehatan, hendaknya dikelola dengan baik untuk meningkatkan kualitas pelayanan kesehatan, seperti yang tercantum dalam UUD 1945 pasal 34 ayat 3 bahwa Negara bertanggung jawab atas penyediaan fasilitas pelayanan kesehatan dan fasilitas pelayanan umum yang layak. Tingkat pendidikan masyarakat yang semakin membaik sehingga menimbulkan kecenderungan untuk menuntut pelayanan umum yang lebih baik dan lebih cepat. Keberadaan rumah sakit baik swasta maupun milik pemerintah serta munculnya klinik-klinik kesehatan di kota besar menyebabkan terjadi persaingan yang ketat dalam menyediakan jasa pelayanan kesehatan. Salah satu strategi yang digunakan oleh pengelola rumah sakit pada umumnya adalah dengan memberikan pelayanan yang berkualitas. Hal ini mengacu kepada UUD 1945 pasal 28H bahwa setiap orang berhak memperoleh pelayanan kesehatan.

Tidak dapat dipungkiri bahwa masyarakat memiliki penilaian terhadap kualitas jasa pada tiap-tiap rumah sakit, yang tentu saja berbeda antara rumah sakit swasta dan pemerintah. Oleh karena itu, seharusnya semua rumah sakit melakukan pelayanan kesehatan sesuai standar dan mendapat sanksi yang sama jika melakukan kesalahan untuk menjamin kualitas (MENKES, 2019). Kinerja pelayanan yang diberikan Rumah Sakit Al-Islam Bandung dapat diukur melalui kualitas pelayanan. Ada lima dimensi kualitas pelayanan yang meliputi : reliability (keandalan), responsiveness (ketanggapan), assurance (jaminan), empathy (empati), dan tangibles (keberwujudan) (Fandy Tjiptono, 2019). Pelayanan kesehatan yang berkualitas akan memberikan dampak kepuasan pasien sebagai penerima pelayanan dan akan menyebabkan terjadinya kunjung berulang sehingga akan meningkatkan loyalitas pasien terhadap sarana pelayanan kesehatan serta merupakan tingkat kepatuhan pasien dalam menjalankan pengobatan yang diberikan oleh tenaga kesehatan. Jadi, 
apabila kelima elemen tersebut diperhatikan, maka diharapkan akan memberi kepuasan kepada pasien (Buchari Alma, 2016). Kepuasan adalah perasaan senang atau kecewa seseorang yang muncul setelah membandingkan kinerja (hasil) produk yang dipikirkan terhadap kinerja (atau hasil) yang diharapkan (Kotler \& Keller, 2012). Kepuasan pasien merupakan keluaran dari layanan kesehatan dan suatu perubahan dari sistem layanan kesehatan yang ingin dilakukan. Tidak mungkin tepat sasaran dan berhasil tanpa melakukan pengukuran kepuasan pasien, karena hasil pengukuran kepuasan pasien akan digunakan sebagai dasar untuk mendukung perubahan sistem layanan kesehatan, perangkat yang digunakan untuk mengukur kepuasan pasien harus handal dan dapat dipercaya.

Beberapa peneliti telah mengemukakan hasil dari pengaruh kualitas pelayanan terhadap kepuasan pasien. Indikator tertinggi pada variabel kualitas pelayanan yaitu pada indikator ketampakan fisik, untuk indikator terendah pada indikator responsivitas, sedangkan pada variabel kepuasan pasien yaitu pada indikator keamanan, untuk indikator terendah kelengkapan (Mahfudhoh \& Muslimin, 2020). Item-item yang berpengaruh adalah kehandalan, daya tanggap, dan empati, sedangkan jaminan dan sarana fisik tidak berpengaruh terhadap kepuasan pasien rawat inap (Jacobis, 2013). Kualitas pelayanan berpengaruh positif dan signifikan terhadap kepuasan pasien dan loyalitas pasien, kepuasan pasien berpengaruh positif dan signifikan terhadap loyalitas pasien (Dewi, 2016). Bukti fisik (tangibles) dan ketanggapan (responsiveness) berpengaruh positif dan signifikan terhadap kepuasan, sedangkan kehandalan (reliability), jaminan (assurance), dan empati (empathy) tidak berpengaruh positif dan signifikan terhadap kepuasan (Rani et al., 2020)

\section{METODE PENELITIAN}

Penelitian dilakukan di Rumah Sakit Al-Islam (RSAI) Bandung yang berlokasi di J1. Soekarno Hatta No.644 Kelurahan Manjahlega Kecamatan Rancasari Kota Bandung. Objek penelitian ini adalah kualitas pelayanan yang terdiri dari Tangible (keberwujudan), Empathy (empati), Responsiveness (ketanggapan), Reliability (keandalan), Assurance (jaminan) dan kepuasan pasien rawat inap RSAI Bandung. Populasi dalam penelitian ini adalah pasien yang dirawat inap di RSAI Bandung sebanyak 107 orang. Metode sampling yang digunakan untuk menarik sampel ada- 
lah probability sampling. Sedangkan teknik sampling yang digunakan adalah proportionate stratified random sampling. Dengan menggunakan rumus dari Slovin dan menggunakan taraf kesalahan (e) sebesar 5\%, maka jumlah sampel yang di ambil sebanyak 84 orang yang terdiri dari 16 orang pasien rawat inap di kelas VIP, 20 orang pasien rawat inap di kelas I, 27 orang pasien rawat inap di kelas II dan 21 orang pasien rawat inap di kelas III.

Metode penelitian yang digunakan adalah metode penelitian survey. Jenis penelitian ini merupakan explanatory research. Teknik pengumpulan data yang dilakukan melalui wawancara, kuesioner, observasi dan penelitian kepustakaan. Uji kualitas data dilakukan dengan uji validitas dan uji reliabilitas. Uji hipotesis dilakukan secara parsial dan keseluruhan. Teknik analisis data dalam penelitian kuantitatif ini menggunakan statistik inferensial, Untuk memperkuat analisis, digunakan analisis korelatif yang dilanjutkan dengan analisis jalur (path analysis). Berdasarkan perhitungan korelasi yang terlihat pada hasil analisis jalur, maka diperoleh koefisien determinasi.

\section{HASIL DAN PEMBAHASAN}

Hubungan antar variabel yang diteliti disajikan dalam tabel berikut :

Tabel 1. Correlations

\begin{tabular}{|c|c|c|c|c|c|c|}
\hline & & $\mathrm{X} 1$ & $\mathrm{X} 2$ & $\mathrm{X} 3$ & $\mathrm{X} 4$ & $\mathrm{X} 5$ \\
\hline \multirow[t]{3}{*}{$\mathrm{X} 1$} & Pearson Correlation & 1 & $449^{* *}$ & $312^{* *}$ &, $064^{* *}$ & $015^{* *}$ \\
\hline & Sig. (2-tailed) & & 000 & 000 &, 000 & 000 \\
\hline & $\mathrm{N}$ & 84 & 84 & 84 & 84 & 84 \\
\hline \multirow[t]{3}{*}{$\mathrm{X} 2$} & Pearson Correlation & $449^{* *}$ & 1 & $367^{* *}$ & $156^{* *}$ & $101^{* *}$ \\
\hline & Sig. (2-tailed) &, 000 & &, 000 &, 000 &, 000 \\
\hline & $\mathrm{N}$ & 84 & 84 & 84 & 84 & 84 \\
\hline \multirow[t]{3}{*}{$\mathrm{X} 3$} & Pearson Correlation &, $312^{* *}$ &, $367^{* *}$ & 1 & $170^{* *}$ & $149^{* *}$ \\
\hline & Sig. (2-tailed) &, 000 &, 000 & &, 000 &, 000 \\
\hline & $\mathrm{N}$ & 84 & 84 & 84 & 84 & 84 \\
\hline \multirow[t]{3}{*}{$\mathrm{X} 4$} & Pearson Correlation &, $064^{* *}$ &, $156^{* *}$ &, $170^{* *}$ & 1 & $350^{* *}$ \\
\hline & Sig. (2-tailed) &, 000 &, 000 &, 000 & &, 000 \\
\hline & $\mathrm{N}$ & 84 & 84 & 84 & 84 & 84 \\
\hline \multirow[t]{3}{*}{ X5 } & Pearson Correlation &, $015^{* *}$ &, $101^{* *}$ & $149^{* *}$ & ,350** & 1 \\
\hline & Sig. (2-tailed) &, 000 &, 000 &, 000 &, 000 & \\
\hline & $\mathrm{N}$ & 84 & 84 & 84 & 84 & 84 \\
\hline
\end{tabular}

Sumber : Hasil Perhitungan Statistik 
Sesuai dengan tabel diatas terlihat hubungan antar variabel memenuhi kategori signifikan pada level 1\% dan 5\%, dengan demikian semua variabel dapat diolah lebih lanjut.

Hasil pengujian jalur (Path Analysis) dengan menggunakan software SPSS v.18 diperoleh hasil sebagai berikut :

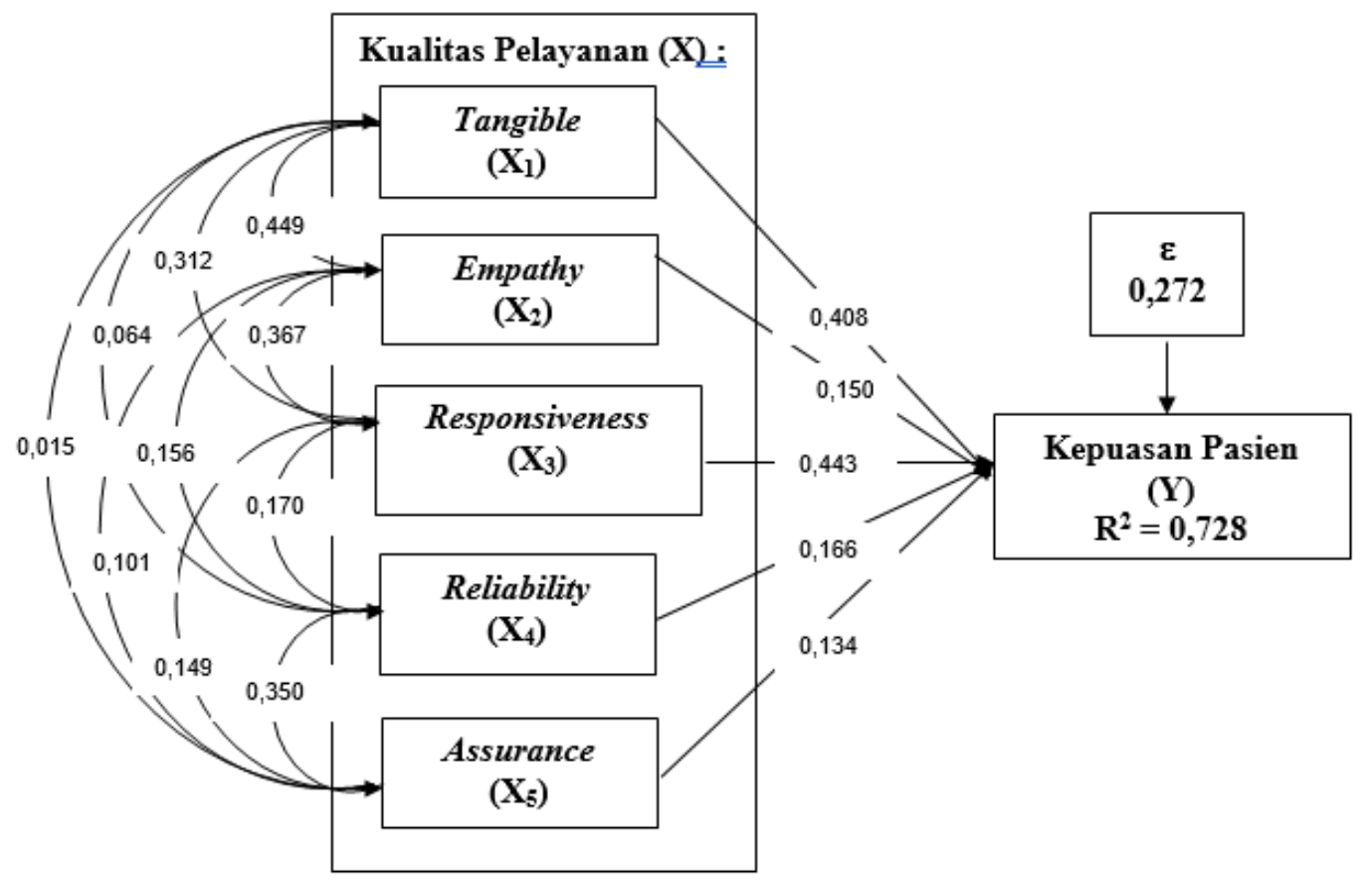

Gambar 1: Hasil Pengujian Jalur

Melalui gambar 1 diatas dapat diformulasikan hasil pengujian melalui tabel berikut :

Tabel 2. Hasil Perhitungan Jalur

\begin{tabular}{cc}
\hline Variabel & Koefisien Jalur \\
\hline Tangible / Keberwujudan $\left(\mathbf{X}_{\mathbf{1}}\right)$ & 0,408 \\
\hline Empathy / Empati $\left(\mathbf{X}_{\mathbf{2}}\right)$ & 0,150 \\
\hline Responsiveness / Ketanggapan & 0,443 \\
$\left(\mathbf{X}_{3}\right)$ & \\
\hline Reliability / Keandalan $\left(\mathbf{X}_{\mathbf{4}}\right)$ & 0,166 \\
\hline Assurance / Jaminan $\left(\mathbf{X}_{5}\right)$ & 0,134 \\
\hline
\end{tabular}

Sumber : Hasil Perhitungan Statistik 
Dengan memperhatikan tabel 2 diperoleh persamaan jalur, yaitu :

$$
\mathrm{Y}=0,408 \mathrm{X}_{1}+0,150 \mathrm{X}_{2}+0,443 \mathrm{X}_{3}+0,166 \mathrm{X}_{4}+0,134 \mathrm{X}_{5}+\varepsilon
$$

Pengaruh langsung dan tidak langsung setiap variabel disajikan dalam tabel berikut :

Tabel 3. Pengaruh Langsung dan Tidak Langsung

\begin{tabular}{|c|c|c|c|c|c|c|c|}
\hline \multirow{3}{*}{$\begin{array}{c}\text { Kualitas } \\
\text { Pelayanan (X) }\end{array}$} & \multicolumn{6}{|c|}{ Kepuasan Pasien (Y) } & \multirow[t]{3}{*}{ Total } \\
\hline & \multirow{2}{*}{$\begin{array}{l}\text { Pengaruh } \\
\text { langsung }\end{array}$} & \multicolumn{5}{|c|}{ Pengaruh Tidak Langsung } & \\
\hline & & $\mathbf{X 1}$ & $\mathrm{X} 2$ & $\mathbf{X 3}$ & X4 & $\mathbf{X 5}$ & \\
\hline $\begin{array}{c}\text { Tangible / } \\
\text { Keberwujudan } \\
\left(\mathrm{X}_{1}\right)\end{array}$ & $16,65 \%$ & & $2,75 \%$ & $5,64 \%$ & $0,43 \%$ & $0,08 \%$ & $25,55 \%$ \\
\hline $\begin{array}{c}\text { Empathy / } \\
\text { Empati }\left(\mathrm{X}_{2}\right)\end{array}$ & $2,25 \%$ & $2,75 \%$ & & $2,44 \%$ & $0,39 \%$ & $0,20 \%$ & $8,03 \%$ \\
\hline $\begin{array}{c}\text { Responsiveness } \\
\text { / Ketanggapan } \\
\left(\mathrm{X}_{3}\right)\end{array}$ & $19,62 \%$ & $5,64 \%$ & $2,44 \%$ & & $1,25 \%$ & $0,88 \%$ & $29,83 \%$ \\
\hline $\begin{array}{l}\text { Reliability / } \\
\text { Keandalan } \\
\left(\mathrm{X}_{4}\right)\end{array}$ & $2,76 \%$ & $0,43 \%$ & $0,39 \%$ & $1,25 \%$ & & $0,78 \%$ & $5,61 \%$ \\
\hline $\begin{array}{c}\text { Assurance / } \\
\text { Jaminan (X5) }\end{array}$ & $1,80 \%$ & $0,08 \%$ & $0,20 \%$ & $0,88 \%$ & $0,78 \%$ & & $3,74 \%$ \\
\hline Efek Total & $43,08 \%$ & $8,90 \%$ & $5,78 \%$ & $10,21 \%$ & $2,85 \%$ & $1,94 \%$ & $72,76 \%$ \\
\hline
\end{tabular}

Tabel. 4 Kriteria Penafsiran Hubungan dan Pengaruh Antar Variabel

\begin{tabular}{|c|c|c|}
\hline Hasil Pengolahan & Hubungan & Pengaruh \\
\hline $0,000-0,199$ & Sangat Lemah & Sangat Lemah \\
\hline $0,200-0,399$ & Lemah & Lemah \\
\hline $0,400-0,599$ & Cukup Kuat & Cukup Kuat \\
\hline $0,600-0,799$ & Kuat & Kuat \\
\hline $0,800-1,000$ & Sangat Kuat & Sangat Kuat \\
\hline
\end{tabular}

Sumber : (Sugiyono, 2018)

Determinasi yang diperoleh menunjukkan bahwa :

Tabel 5. Model Summary

\begin{tabular}{ccccr}
\hline Model & $\mathbf{R}$ & $\begin{array}{c}\mathbf{R} \\
\text { Square }\end{array}$ & $\begin{array}{c}\text { Adjusted R } \\
\text { Square }\end{array}$ & $\begin{array}{r}\text { Std. Error of } \\
\text { the Estimate }\end{array}$ \\
\hline 1 &, $853^{\mathrm{a}}$ &, 728 &, 711 & 3,09303 \\
\hline
\end{tabular}

a. Predictors: (Constant), X5, X1, X4, X2, X3

Sumber : Hasil Perhitungan Statistik 
Kontribusi Tangible $\left(\mathrm{X}_{1}\right)$, Empathy $\left(\mathrm{X}_{2}\right)$, Responsiveness $\left(\mathrm{X}_{3}\right)$, Reliability $\left(\mathrm{X}_{4}\right)$, Assurance $\left(\mathrm{X}_{5}\right)$ terhadap kepuasan pasien $(\mathrm{Y})$ diperoleh sebesar $72,8 \%$, sedangkan sisanya sebesar $27,2 \%$ dijelaskan oleh variabel lain yang tidak diteliti.

Total pengaruh keberwujudan terhadap kepuasan pasien termasuk kategori lemah kontribusinya. Hal ini bisa disebabkan karena responden tidak terlalu memperhatikan keadaan fisik rumah sakit dan hanya merasa bahwa Rumah Sakit Al-Islam Bandung merupakan rumah sakit besar yang berada di wilayah Bandung Timur dan mudah dijangkau.

Total pengaruh empati terhadap kepuasan pasien termasuk kategori sangat lemah kontribusinya. Hal ini bisa disebabkan karena pasien hanya berkeinginan untuk sembuh, tidak mempedulikan adanya sebagian petugas yang tidak sabar, tidak mengerti dan ketidaknyamanan pada saat pelayanan diberikan.

Total pengaruh ketanggapan terhadap kepusan pasien termasuk kategori lemah kontribusinya. Hal ini bisa disebabkan karena proses penyelesaian administrasi baik bagi pasien yang mampu maupun yang tidak mampu kurang cepat ditanggapi. Total pengaruh keandalan terhadap kepuasan pasien termasuk kategori sangat lemah kontribusinya. Hal ini bisa disebabkan karena dokter atau perawat dalam memberikan janji untuk memberi pelayanan tidak tepat waktu.

Total pengaruh jaminan terhadap kepuasan pasien termasuk kategori sangat lemah kontribusinya. Hal ini bisa disebabkan karena yang terpenting menurut pasien adalah bagaimana mereka mendapat pelayanan walaupun ada perlakuan khusus terhadap pasien tertentu oleh sebagian petugas tetapi pasien lainnya tidak merasakannya.

Dilihat pengaruhnya secara parsial terhadap kepuasan pasien, sebagian besar variabel kualitas pelayanan adalah lemah. Hal ini bisa disebabkan dari masing-masing kriteria variabel tersebut masih ada permasalahan yang muncul, sehingga dapat dikatakan bahwa Rumah Sakit Al-Islam Bandung belum maksimal dalam memberikan jasa pelayanan terhadap kepuasan pasien.

Namun berdasarkan hasil gambaran tanggapan responden dari setiap hasil penelitian pengaruh kualitas layanan terhadap kepuasan pasien secara simultan 
ternyata pengaruhnya kuat. Dari hasil tersebut dapat dikatakan penerapan kualitas layanan kepada pasien tidak bisa dipilah-pilah berdasarkan dimensi Keberwujudan, Empati, Ketanggapan, Keandalan, Jaminan, tetapi harus diterapkan secara terintegrasi, sehingga memiliki pengaruh yang kuat terhadap kepuasan pasien.

\section{SIMPULAN}

Sesuai hasil penelitian dan pembahasan yang dilakukan, didapatkan kesimpulan bahwa tingkat Tangible (keberwujudan), Empathy (empati) dan Responsiveness (ketanggapan termasuk dalam kategori sangat baik, sedangkan tingkat Reliability (keandalan) dan Assurance (jaminan) termasuk dalam kategori baik, sehingga tingkat kepuasan pasien rawat inap di Rumah Sakit Al-Islam Bandung termasuk dalam kategori sangat baik. Besarnya pengaruh Tangible (keberwujudan) dan Responsiveness (ketanggapan) terhadap kepuasan pasien rawat inap di Rumah Sakit Al-Islam Bandung termasuk dalam kategori lemah pengaruhnya, sedangkan besarnya pengaruh Empathy (empati), Reliability (keandalan) dan Assurance (jaminan) termasuk dalam kategori sangat lemah pengaruhnya. Namun besarnya pengaruh Tangible (keberwujudan), Empathy (empati), Responsiveness (ketanggapan), Reliability (keandalan), Assurance (jaminan) pelayanan terhadap kepuasan pasien rawat inap di Rumah Sakit Al-Islam Bandung termasuk dalam kategori kuat pengaruhnya.

Dari hasil penelitian terlihat bahwa masih adanya ketidaksesuaian antara harapan dan kenyataan yang dirasakan oleh pasien maupun keluarga pasien dalam hal pelayanan yang diberikan oleh pihak Rumah Sakit sehingga muncul rasa ketidakpuasan, oleh sebab itu penulis menyarankan untuk variabel Tangible (keberwujudan) sebaiknya fasilitas fisik seperti ruang perawatan, ruang tunggu / mushola dan toilet ditampilkan dengan baik, menarik dan terawat. Untuk variabel Empathy (empati) sebaiknya pihak rumah sakit lebih peduli dalam memberikan perhatian dan kebutuhan pasien serta sabar dalam menghadapi pasien / keluarganya sehingga pasien / keluarganya bisa berhubungan dengan nyaman dengan pihak rumah sakit. Untuk variabel Responsiveness (ketanggapan) sebaiknya pihak rumah sakit memberikan pelayanan dengan segera / cepat terutama dalam proses administrasi serta ditanamkan rasa keinginan / kemauan untuk membantu pasien. Untuk variabel Reliability (keandalan) sebaiknya pihak rumah sakit tepat waktu sesuai dengan yang di- 
janjikan dalam memberikan pelayanan kepada pasien. Untuk variabel Assurance (jaminan) sebaiknya pihak rumah sakit tidak memberikan perlakuan secara khusus kepada pasien tertentu, tanamkan kepercayaan kepada pasien sehingga pasien merasa aman dalam berinteraksi dengan orang / pihak rumah sakit.

\section{DAFTAR PUSTAKA}

Buchari Alma. (2016). Manajemen Pemasaran dan Pemasaran Jasa. Bandung : Alfabeta.

Dewi, R. R. (2016). Pengaruh Kualitas Pelayanan Terhadap Loyalitas Pasien Pengguna BPJS Dengan Kepuasan Pasien Sebagai Variabel Intervening. Jurnal Ekonomi Manajemen Sumber Daya, 18 No.2(Desember), 146-156. doi: https://doi.org/10.23917/dayasaing.v18i2.4511

Fandy Tjiptono. (2019). Pemasaran Jasa : Prinsip, Penerapan, Penelitian. Yogyakarta : Andi.

Jacobis, R. (2013). Faktor-Faktor Kualitas Pelayanan Pengaruhnya Terhadap Kepuasan Pasien Rawat Inap Peserta Jamkesmas Di BLU RSUP Prof DR R. D. Kandou Manado. Jurnal Riset Ekonomi, Manajemen, Bisnis Dan Akuntansi Akuntansi, 1 No.4(Desember), 619-629. doi: https://doi.org/10.35794/emba.v1i4.2742

Kotler, P., \& Keller, K. L. (2012). Marketing Management (14th ed.). Jakarta : Erlangga.

Mahfudhoh, M., \& Muslimin, I. (2020). Pengaruh Kualitas Pelayanan Terhadap Kepuasan Pasien Pada Rumah Sakit Umum Daerah Kota Cilegon. Jurnal Ilmiah Manajemen Kesatuan, 8 No.1(April), 39-46. doi: https://doi.org/10.37641/jimkes.v8i1.310

MENKES. (2019). Standar Teknis Pemenuhan Mutu Pelayanan Dasar Pada Standar Pelayanan Minimal Bidang Kesehatan (Permenkes Nomor 4 Tahun 2019). https://www.jogloabang.com/permenkes-4-th-2019-standar-teknispemenuhan-mutu-pelayanan-dasar-standar-pelayanan-minimal-bidang

Rani, M., Basalamah, S., \& Damis, H. (2020). Pengaruh Kualitas Pelayanan Terhadap Kepuasan Pasien Rawat Inap di Ruang Perawatan Private Care Center (PCC) RSUP Dr. Wahidin Sudirohusodo Makassar. Tata Kelola, 7 No.2(Desember), 95-113. http: pasca-umi.ac.id/index.php/tata

Sugiyono. (2018). Metode Penelitian Kuantitatif, Kualitatif dan R\&D. Bandung : Alfabeta. 